\title{
HEDONIC CONSUMPTION CHARACTERISTICS RELATED TO PRODUCTS AND SERVICES WHERE FASHION INVOLVEMENT PLAYS AN IMPORTANT ROLE, A FIELD STUDY FROM ESKISEHIR, TURKEY
}

\author{
CELIL KOPARAL, NURI ÇALIK
}

\begin{abstract}
:
This study intends to find out the relationship between hedonic consumption and consumers' demographic and psychographic traits as within the scope of fashion goods and expensive services. A survey is applied to 1020 respondents selected via stratified sampling from Eskişehir, a city of Turkey with 700.000 inhabitants. The respondents are required to answer 44 questions of which five are related to demographic characteristics of these respondents. The rest 39 are statements which are designed to reflect the hedonic consumption behavior of these people. The study consists of five parts. The first part is an introduction where the scope and the purpose of the study are concisely stated. The second part relates to the theoretical background of the subject matter and the prior researches carried out so far. The third part deals with research methodology, basic premises and hypotheses attached to these premises. Research model and analyses take place in this section. Theoretical framework is built and a variable name is assigned to each of the question asked or proposition forwarded to the respondents of this survey. 39 statements or propositions given to the respondents are placed on a five-point Likert scale where 1 stands for 'strongly disagree' and 5 represents 'strongly agree'. The remaining five questions about demographic traits as age, gender, occupation, educational level and monthly income are placed either on a nominal or ratio scale with respect to the nature of the trait. Ten research hypotheses are formulated in this section. The fourth part mainly deals with the results of the hypothesis tests and bivariate and multivariate analysis is applied to the data on hand. Here exploratory factor analysis reduces 39 variables to six basic components. In addition non-parametric biraviate analysis in terms of Chi-Square is applied to test the hypotheses formulated in this respect. The fifth part is the conclusion where findings of this survey are listed.
\end{abstract}

\section{Keywords:}

fashion involvement, life styles, materialistic thinking, hedonic consumption

\section{Authors:}

CELIL KOPARAL, Anadolu University, Turkey, Email: ckoparal@anadolu.edu.tr NURI ÇALIK, Anadolu University, Turkey, Email: ncalik@anadolu.edu.tr

\section{Citation:}

CELIL KOPARAL, NURI ÇALIK (2015). Hedonic Consumption Characteristics Related to Products and Services where Fashion Involvement Plays an Important Role, A Field Study from Eskisehir, Turkey. 
International Journal of Social Sciences, Vol. IV(1), pp. 14-39., 10.20472/SS2015.4.1.002 


\section{Introduction}

Hedonic consumption from marketing point of view, is a concept that underlines the consumers' behavior which is tied to the multisensory, fantasy and emotional aspects of product usage experience; where individuals purchase products not only for what they can do, but also for what they mean (Hirschman p.92), and the term 'multisensory' points at the receipt of experience in multiple sensory modalities such as tastes, sounds, scents, tactile expressions and visual images. Michael R. Solomon, in his book titled as "Consumer Behavior- Buying, Having and Being" relates this subject to perceptual process where sensory stimuli affect on the sensory receptors, which in turn lead to exposure attention and interpretation (Solomon, 2004, p.49):

\section{Figure 1. An Overview of the Perceptual Process}

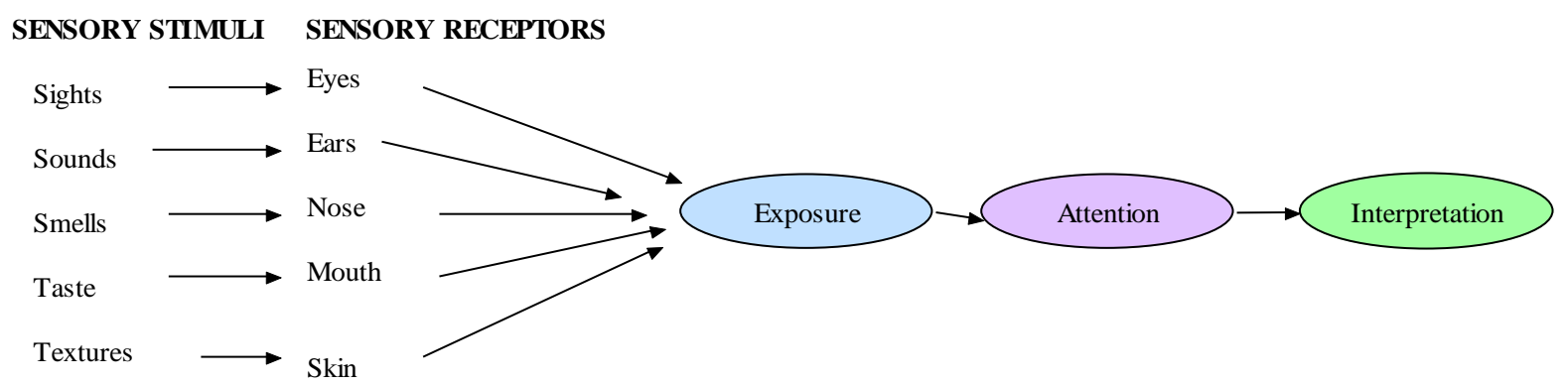

The above representation gives clues about sensation concept, where a sudden response of individual sensory organs (eyes, ears, nose mouth, skin etc.) to outside stimuli such as light, sound, fragrance, texture etc. is asserted. On the other hand perception is a complicated process where these sensations are selected, organized and interpreted. Each noteworthy stimulus from environmental sources is kept by sensory receptors in terms of raw data and starts the perceptual process. In other words, seeing the picture of a sparkling wine, tasting a delicious food, feeling the softness of a sweater, hearing a popular melody or smelling a costly parfume may take a person to his/her old experiences or memories and uses different responses which are the essential parts of hedonic consumption behavior. Apart from multisensory stimuli, emotional arousal is another response type which plays an important role in hedonic consumption. Emotions are connected to motivational factors with neurophysiologic, expressive and experiential components (Izard and Buechler, 1980, p. 93).

\section{Theoretical Background and Prior Studies}

\section{Fashion Oriented Impulse Buying Behavior}

Impulse is defined as "a process that occurs when the consumer experiences a sudden urge to purchase an item that he or she cannot resist" (Solomon, p.598). Many researchers in this respect contributed to theoretical structure by relating 
several psychological variables such as personality and self regulation; hedonic experiences as shopping enjoyment, emotional state and mood; and situational variables as available time and money to impulse behavior (Kim and Forney, p.433). This relationship suggests that hedonic consumption propped by other emotional factors encourages impulse buying behavior. According to Sato and Verplanken "Impulsive buying grossly violates the assumptions of homo economicus. A variety of perspectives on impulse buying are presented, which have been put forward in consumer, economic, social, and clinical psychology. These include heuristic information processing, time-inconsistent preferences, personality traits and values, self-identity, emotions, conscious self-control, and compulsive buying" ( Sato and Verplanken, 2011, p. 197).

\subsection{Fashion Interest and Compulsive Buying}

Compulsive buying behavior is another form of buying which is still confused with impulse buying although these two are quite different concepts. The major difference between them as follows: "Impulsive buying is motivated by an external trigger such as a product near the cash register. Compulsive buying is motivated by an internal trigger such as stress or anxiety, and shopping and spending is an escape from the internal trigger. Compulsive buying can develop into addictive buying when it becomes s a need to continuously spend in order to alleviate stress and anxiety" (Johnson and Atman, p.394). Another definition of compulsive buying is given by Michael R. Solomon: "Compulsive consumption is the process of repetitive, often excessive shopping used to relieve tension, anxiety, depression, or boredom".

A number of psycho-graphical attributes can be assigned to those consumer who frequently succumb to compulsive buying as, low self-esteem, depression, anxiety, materialism, excitement seeking, impulsiveness, and low emotional stability/high neuroticism (Johnson and Attman, p. 395). Further researches reveal that compulsive buying behavior is highly related with the purchase of fashion clothing which will contribute to their physical appearance and attractiveness where fashion marketplace continuously invites and attracts compulsive buyers. Materialism on the other hand is described as: "the importance that possession plays in an individuals life and at the highest level of materialism, possessions assume a central place in an individuals life and are believed by the materialist to be a means of providing satisfaction" (Ryan and Dziurawiec, p.185). The following figure depicts the causal relationship between compulsive clothing buying and above-mentioned factors (Johnson and Attman, p.398): 
Figure 2. Relationships among Neuroticism, Materialism, Fashion Interest, and Compulsive Clothing Buying

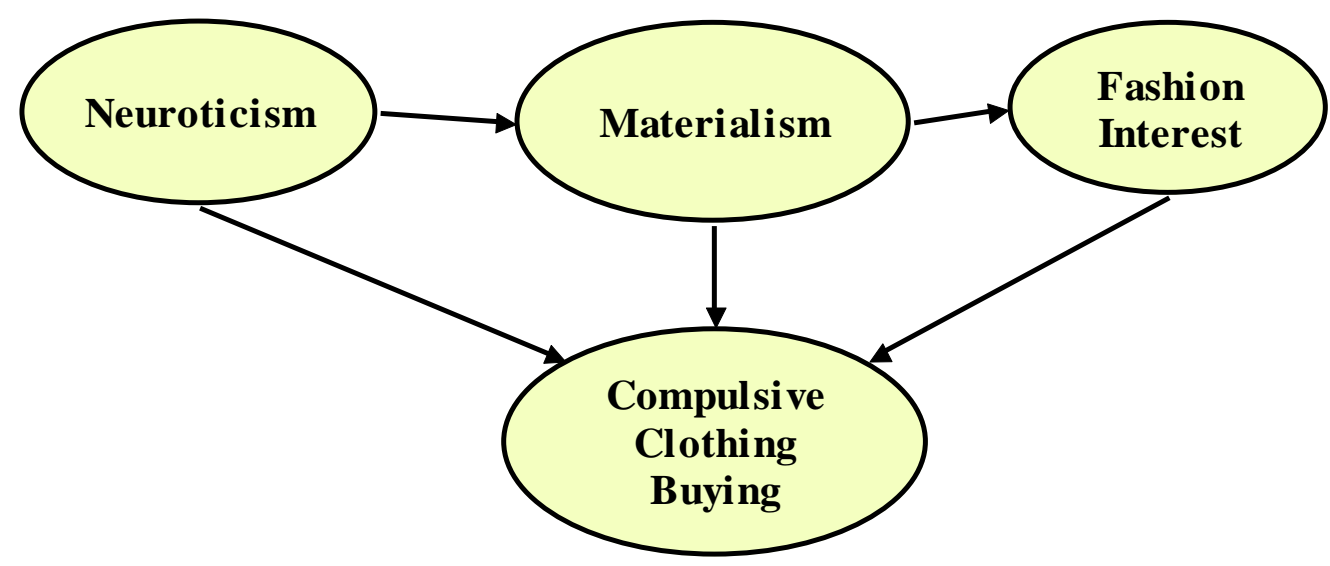

\subsection{Consumer Expertise, Price Consciousness, and Hedonic Orientation}

Consumer expertise is defined as "the ability to perform product-related tasks successfully and composed of five dimensions: cognitive effort, automat city, cognitive structure, analysis and elaboration" (Alba and Hutchinson, 1987, p. 411). Cognitive effort and automaticity refer less effort, easiness in decision making and lack of conscious control since such a consumer is familiar and have experience on the product to be purchased. Cognitive structure on the other hand denotes the information depending on facts and beliefs about a product. Analysis, as the name implies, is the process in a purchase decision where relevant information is adopted and irrelevant information is discarded. Finally elaboration is updating and keeping the necessary information in memory for further use. Price consciousness in this context is defined as how price is regarded as a sign of quality. Here consumers are categorized under two main groups as 'experts' on certain products and 'novices' whose knowledge on such products is not sufficient. The latter group often utilize extrinsic cues to determine quality; whereas the former group rely upon intrinsic cues such as taste smell and color (Lockshin and Rhodus, 1993, p. 14). The relationship between expertise, hedonic orientation, price consciousness and consumption is given below (Neeley, Sam Min, and Kennett Hensel, p.325):

Figure 3. Factors Leading to Consumption

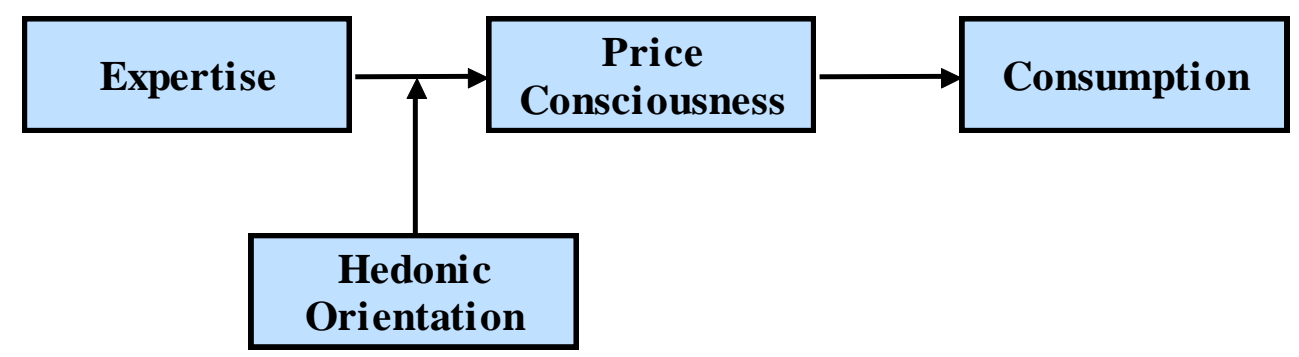




\subsection{Hedonic and Utilitarian Shopping}

Hedonic and utilitarian shopping motivations are directly related with fashion innovativeness and opinion leadership. The market success of a new fashion product depends upon its adoption by a majority of consumers in that market. Fashion leadership is a concept which sinifies the mass acceptance of a new fashion product. Fashion leadership involves two major dimensions: fashion innovativeness and fashion opinion leadership. Innovator is the consumer type who has an ardent desires to purchase a new fashion product before the other consumers. Fashion opinion leader on the other hand, is a reliable person who influences the other consumers on their purchase decisions to buy a fashion product. Consumer fashion buying behavior is triggered by emotional and psychological motivations (Kang and Park-Poaps, p.313). A research carried on the factors affecting female fashion leadership are grouped under two categories as: fashion behaviors, and social values; where fashion behaviors comprise clothing spending, fashion magazine reading, shopping frequency, and new items purchased; and social values include belonging, excitement, fun enjoyment, warm relationships, self-fulfillment, being well respected, accomplishment, security and self-respect (Goldsmith, Freiden, and Kilsheimer, 1993, p. 399). A similar research carried out as two distinct experiments concluded that the key determinant of demand for hedonic practice is the increase in performance efficiency that can be gained through practice, and consequently this kind of practice has different implications on hedonic and utilitarian consumption (Murray and bellman, 2010). Because of the different benefits provided, the trade-offs between hedonic and utilitarian alternatives are systematically influenced by the context of choice (Dhar and Wertenbroch, 2000; Okada, 2005); in a broader sense, this includes the choice set and other characteristics of the choice environment (Palazon Mariola and Delgado-Ballester Elena, p.1258). "The indirect effects of hedonic and utilitarian values on behavioral intentions were also assessed. The Sobel test was used to calculate for mediation in a SEM model. The Sobel test, which was first proposed by Sobel (1982), is by far the most commonly used when testing indirect (mediation) effects. The Sobel test assesses whether a mediator variable (customer satisfaction) significantly carries the effect of an independent variable (hedonic/utilitarian value) to a dependent variable (behavioral intention)".( Ryu Kisang, et. al., p 426): 
Figure 4. Hedonic and Utilitarian Values Explaining Behavioral Intentions Where Customer Satisfaction Acts as an Intervening Variable

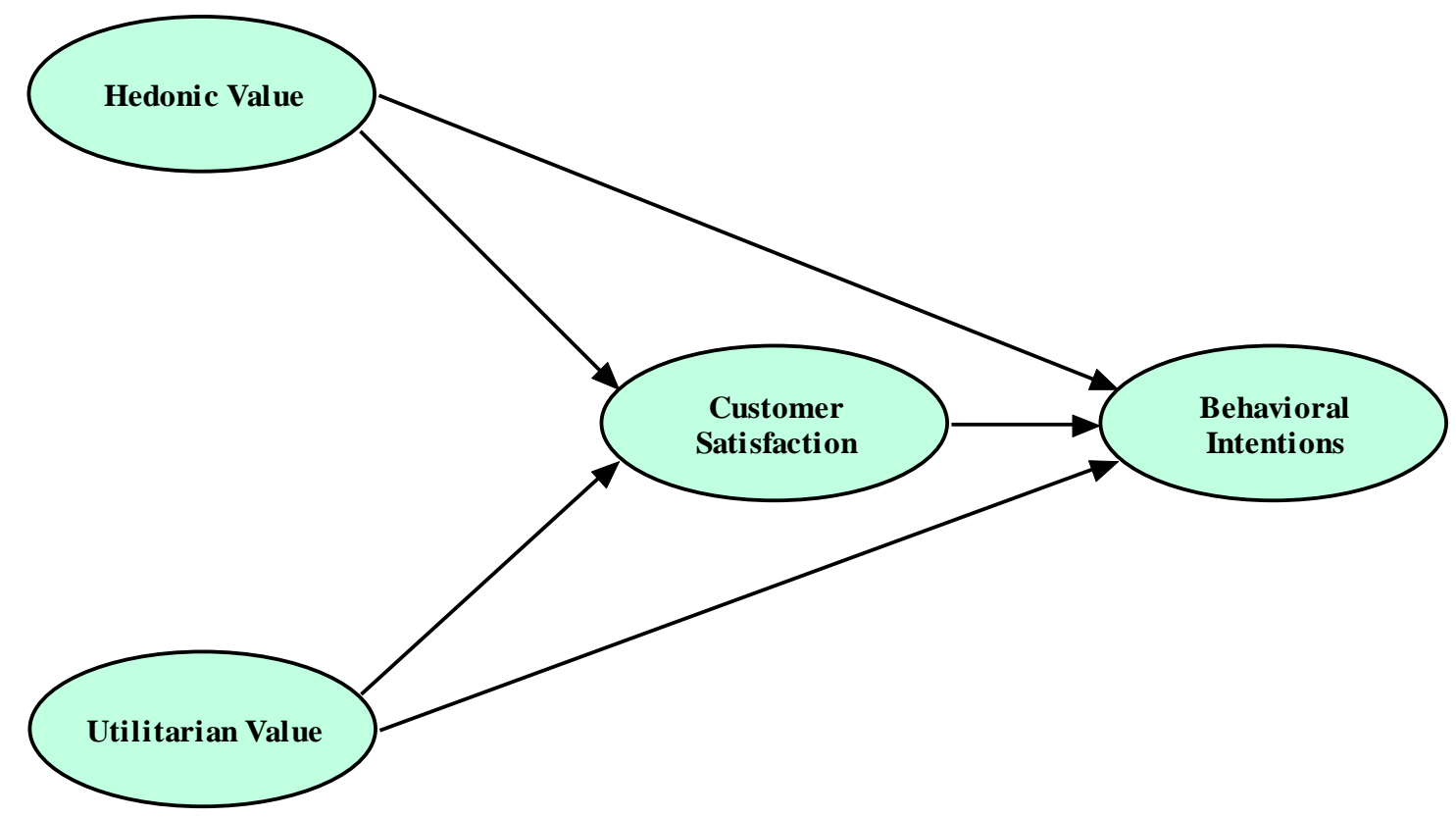

\subsection{Fashion Involvement}

"Involvement is the feeling or emotion characterized by interest, enthusiasm, and excitement that consumers feel for some product categories. When consumers are aroused by a product category in which they are interested, they pay more attention to information (advertisements) about that category, process the information more deeply, and have better memory (knowledge structure)of the information" (Goldsmith, p. 282). To understand the meaning of fashion involvement, satisfaction concept plays an important role. Satisfaction can be related to what possessions have or have not been acquired. It should not be forgotten that the road to satisfaction is highlighted by a common saying as "to have is to be". Fashion clothing denotes a significant position in society. ( $\left.\mathrm{O}^{\prime} \mathrm{Cas}, \mathrm{p} .869\right)$. The antecedents and consequences of fashion clothing is shown beow (O'Cas, p.870): 
Figure 5. Factors Affecting and the Consequences Drawn from Fashion Involvement

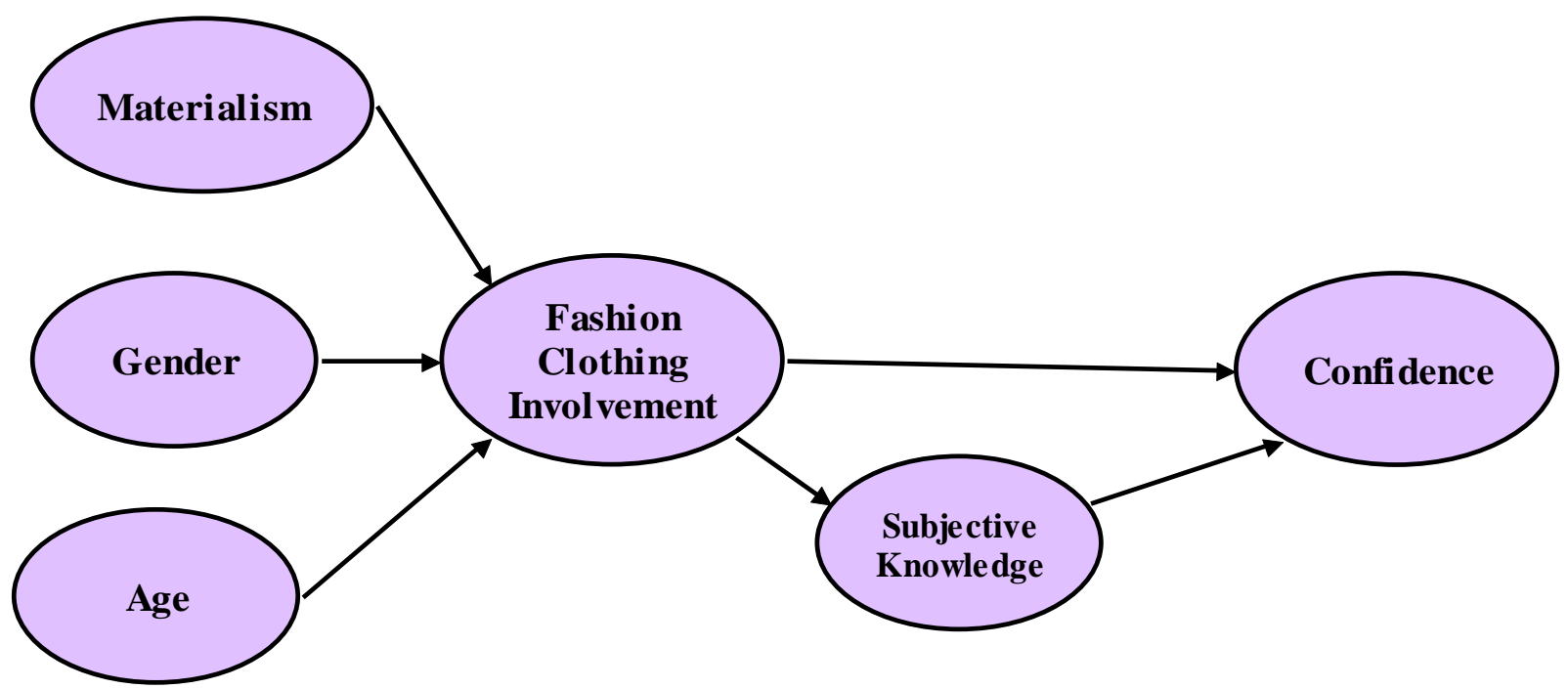

\section{Research Model and Hypotheses}

This field research was conducted in May 2011 in Eskisehir, Turkey, a large city with 700,000 inhabitants. 1200 consumers were selected on a random basis using the Stratified Sampling Method, of which 1020 were found eligible to be included in the research project. Sixty-four senior students taking a "Marketing Research" course were selected as pollsters and given extra credits for collecting reliable information. The respondents were required to answer a total of 44 questions, of which 39 statements were of the five-point Likert scale type ranging from " $1=$ strongly disagree" to " $5=$ strongly agree." The survey also included one ordinal scale type and five nominal and interval type demographic questions. The survey is composed of eight main parts. The first part is composed of eight statements examining fashion involvement of consumers. The second part comprises five statements reflecting price sensitivity. The third part deals with hedonist consumer characteristics through six statements. The fourth part which is hedonic orientation includes seven statements from involvement in products and services point of view. Four statements in the fifth part are about brand loyalty, innovativeness and opinion leadership. The sixth part is personality and composed of four statements. Four statements in the seventh part refer to materialism. Finally five questions in the eighth part are of demographic nature. Each question is taken as a distinct variable that reflects either the behavior or the characteristics of the consumers. The variables used in the analyses and their explanations are as follows: 
Table 1. Variables and Their Explanations

\begin{tabular}{|c|c|c|c|}
\hline Variable & Explanation & Mean & SD \\
\hline \multicolumn{4}{|c|}{ Part 1 fashion involvement of consumers } \\
\hline NOCOMFOR & $\begin{array}{l}\text { I usually dress for fashion,; comfort is only of secodary } \\
\text { importance to me. }\end{array}$ & 2.01 & 1.14 \\
\hline BOUTIQUE & $\begin{array}{l}\text { I am interested in shopping at boutique or fashion } \\
\text { specialty stores rather than at department stores or } \\
\text { other discount stores }\end{array}$ & 2.63 & 1.10 \\
\hline DRESSMAR & Dressing smartly is a philosophy in my life & 3.07 & 1.78 \\
\hline FASHDEFI & $\begin{array}{l}\text { Fashion does not mean spending extravagantly I can } \\
\text { also get fashion goods without spending a lot of money. }\end{array}$ & 3.80 & 1.12 \\
\hline PLEASURE & $\begin{array}{l}\text { It gives me pleasure to buy high-priced clothes and } \\
\text { other fashion items. }\end{array}$ & 2.85 & 1.27 \\
\hline FASHFOLL & $\begin{array}{l}\text { I am known as a "fashion-follower" among my friends } \\
\text { and my family, and I like to be a pioneer in possessing } \\
\text { latest creations even though they are too expensive }\end{array}$ & 2.38 & 1.22 \\
\hline IMPRESSI & $\begin{array}{l}\text { When I buy a fashion product I am sure that it would } \\
\text { make a good impression on other people }\end{array}$ & 2.99 & 1.12 \\
\hline LAGGARD & $\begin{array}{l}\text { In general, I am among the last in my circle of friends to } \\
\text { buy follow fashion goods and other spicialty items. }\end{array}$ & 2.81 & 1.54 \\
\hline \multicolumn{4}{|c|}{ Part 2 price sensitivity } \\
\hline FEELDIST & $\begin{array}{l}\text { Buying the most expensive brand of a fashion product } \\
\text { makes me feel distinguished. }\end{array}$ & 2.62 & 1.19 \\
\hline HAPPINES & It is certainly true that money brings happiness. & 3.24 & 1.25 \\
\hline CHOOSEXP & $\begin{array}{l}\text { I feel it is impressive to choose a relatively more } \\
\text { expensive fashion product even a cheaper equivalent is } \\
\text { available in the stores. }\end{array}$ & 2.29 & 1.23 \\
\hline WRTHPAYN & $\begin{array}{l}\text { Real good clothing and other valuable specialty items } \\
\text { are worth paying a lot of money for. }\end{array}$ & 3.31 & 1.20 \\
\hline CHEAPITE & $\begin{array}{l}\text { If I constantly search for cheap items, other people will } \\
\text { think of me as a stingy person. }\end{array}$ & 2.74 & 1.19 \\
\hline \multicolumn{4}{|c|}{ Part 3 hedonist consumer characteristics } \\
\hline IMPATIEN & $\begin{array}{l}\text { I think I am impatient - If I want to possess something } \\
\text { I buy it readily and quickly }\end{array}$ & 2.88 & 1.36 \\
\hline EXCITEMT & $\begin{array}{l}\text { Excitement and adventures is indispensable part of my } \\
\text { life }\end{array}$ & 3.18 & 1.26 \\
\hline STRNGIMP & $\begin{array}{l}\text { I search for strong impressions and experiences in my } \\
\text { free time, they help me to loosen from everyday life }\end{array}$ & 3.32 & 1.07 \\
\hline PERSFEAT & $\begin{array}{l}\text { I want to emphasize certain features of my personality } \\
\text { by distinguished services that I use }\end{array}$ & 2.99 & 1.12 \\
\hline
\end{tabular}




\begin{tabular}{|c|c|c|c|}
\hline MDERNIMP & $\begin{array}{l}\text { Using fashion goods and leading my life in luxury gives } \\
\text { a modern impression of myself to other people. }\end{array}$ & 2.91 & 1.12 \\
\hline VISTMALL & $\begin{array}{l}\text { Visiting fashion malls and other specialty stores is quite } \\
\text { a pleasure for me. }\end{array}$ & 2.85 & 1.22 \\
\hline \multicolumn{4}{|c|}{ Part 4 hedonic orientation } \\
\hline FANCYRES & $\begin{array}{l}\text { I prefer fancy (expensive) restaurants and other } \\
\text { amusement places where the weight is given to factors } \\
\text { ambience, food and se }\end{array}$ & 2.70 & 1.20 \\
\hline RELAXTIO & I deserve relaxation as a reward for my daily effort & 4.16 & 0.89 \\
\hline TRTHOFLF & $\begin{array}{l}\text { rate fashion goods, expensive food, drinks and } \\
\text { traveling as the basic truths of my life }\end{array}$ & 2.54 & 1.11 \\
\hline EXPENSIV & $\begin{array}{l}\text { Expensive and high quality goods and services help me } \\
\text { the type of life I strive for. }\end{array}$ & 2.72 & 1.22 \\
\hline USESPECI & $\begin{array}{l}\text { Using specialty items help me to behave in the manner } \\
\text { which I like to behave }\end{array}$ & 2.77 & 1.11 \\
\hline SWTCHBR & $\begin{array}{l}\text { If I could not find my preferred brand of the specialty } \\
\text { item, I can switch to another brand provided that it } \\
\text { possesses more or less the same features. }\end{array}$ & 3.53 & 1.10 \\
\hline SELFRWRD & $\begin{array}{l}\text { I feel I if I had given a present or a reward to myself } \\
\text { whenever I buy expensive cosmetics. }\end{array}$ & 2.92 & 1.29 \\
\hline GOURMET & I am a real gourmet and enjoy food and drink. & 3.35 & 1.08 \\
\hline \multicolumn{4}{|c|}{ Part 5 brand loyalty \& innovativeness \& opinion leadership } \\
\hline LOYALTY & $\begin{array}{l}\text { If my preferred brand of a specialty item were not } \\
\text { available at the store, I would shop at other stores until } \\
\text { I found my brand. }\end{array}$ & 2.69 & 1.23 \\
\hline INNOVATR & $\begin{array}{l}\text { I know more about new fashions and other expensive } \\
\text { novelties before other people do. }\end{array}$ & 2.44 & 1.18 \\
\hline EXPERT & I can classify myself as an expert on fashion clothing. & 2.48 & 1.13 \\
\hline \multicolumn{4}{|c|}{ Part 6 personality } \\
\hline IMPRESS & $\begin{array}{l}\text { I believe that some of the specialty items I buy would } \\
\text { impress other people. }\end{array}$ & 3.41 & 1.07 \\
\hline PRESTIGE & $\begin{array}{l}\text { I fancy the prestige that is accompanied with a high } \\
\text { priced product }\end{array}$ & 2.84 & 1.25 \\
\hline INVLVMNT & $\begin{array}{l}\text { I believe other people judge my personality with respect } \\
\text { to the type and brand of the specialty items that I use. }\end{array}$ & 2.75 & 1.13 \\
\hline POSSEXPE & $\begin{array}{l}\text { My greatest dream in life is to possess something } \\
\text { expensive }\end{array}$ & 2.36 & 1.21 \\
\hline SNOBAPPL & $\begin{array}{l}\text { A product which has snob appeal is more valuable to } \\
\text { me. }\end{array}$ & 2.64 & 1.23 \\
\hline
\end{tabular}




\begin{tabular}{|l|l|l|l|}
\hline ADMRENVY & $\begin{array}{l}\text { I admire and envy people who own expensive and } \\
\text { luxurious possessions such as cars, mansions, } \\
\text { clothing, accessories, electronics etc. }\end{array}$ & 2.47 & 1.16 \\
\hline NOATTENT & $\begin{array}{l}\text { I don't pay attention and develop interest to the material } \\
\text { possessions of the other people. }\end{array}$ & 3.40 & 1.14 \\
\hline LUXURY & I like to have a lot of luxury in my life. & 3.34 & 1.14 \\
\hline BETRLIFE & I could have lead a better life if I owned more luxurious & 2.91 & 1.25 \\
\hline Part 8 consumer demographics & items that I don't currently have & & \\
\hline AGE & Age & 2.07 & 0.93 \\
\hline GENDER & Gender & N.A. & N.A. \\
\hline OCCUPATI & Occupation & N.A. & N.A. \\
\hline EDULEVEL & Educational level & 2.43 & 0.70 \\
\hline INCOMELV & Income level & 2.50 & 1.08 \\
\hline
\end{tabular}

\section{Hypotheses}

A number of research hypotheses are formulated to test the degree of relationships between major factors in hedonic consumption behavior. The first group of hypotheses is between fashion involvement and consumer traits as brand loyalty, innovativeness and opinion leadership:

$\mathrm{H}_{1}=$ Fashion involvement is related significantly to consumer traits in terms of loyalty, innovativeness and opinion leadership.

$\mathrm{H}_{1 \mathrm{a}}=$ Consumers prefer to dress for fashion rather than for comfort.

$\mathrm{H}_{1 \mathrm{~b}}=$ Boutiques and fashion specialty stores appeal to consumers more than department stores and discount stores.

$\mathrm{H}_{1 \mathrm{c}}=$ Dressing smartly is a sign for consumer philosophy.

$\mathrm{H}_{1 \mathrm{~d}}=$ Fashion means extravagance in spending for consumers.

$\mathrm{H}_{1 \mathrm{e}}=$ Consumers get pleasure from high priced clothes and other fashion items.

$\mathrm{H}_{1 f}=$ Brand-loyal consumers, innovators and opinion leaders are known as fashion followers.

$\mathrm{H}_{1 \mathrm{~g}}=$ Fashion involvement and innovativeness is positively related.

Second group of hypotheses reflect the relationship between materialism and compulsive buying behavior. The proposition here is that "materialism is positively and significantly related to compulsive buying behavior":

$\mathrm{H}_{2}=$ Materialism, excitement and impression affects significantly the compulsive buying behavior

$\mathrm{H}_{1 \mathrm{a}}=$ Urges on leading a better life and need for luxurious items triggers compulsive buying in one's purchases.

$\mathrm{H}_{2 b}=$ Consumers with compulsive buying practice yearn for luxury in their lives more than patient buyers. 
$\mathrm{H}_{2 \mathrm{c}}=$ Envying and admiring other people's possessions is a sign of compulsive buying.

$\mathrm{H}_{2 \mathrm{~d}}=$ Materialistic behavior develop an interest to the material possessions of the other people.

Third group of hypotheses are formulated to find out the relationship between the price orientation of consumers and their personalities:

$\mathrm{H}_{3}=$ Price insensitivity of consumers is significantly related to their hedonist personality traits:

$\mathrm{H}_{3 \mathrm{a}}=$ The urge to impress other people leads to expensive purchases.

$\mathrm{H}_{3 \mathrm{~b}}=$ Satisfying prestige needs directs people to purchase high-priced items.

$\mathrm{H}_{3 \mathrm{~d}}=$ Expensive purchases helps one's personality to be judged positively.

$\mathrm{H}_{3 \mathrm{e}}=$ Snob appeal is related positively with expensive spending.

Consumer demographics play an important role in fashion involvement. Fourth group of hypotheses are formulated in this respect:

$\mathrm{H}_{4}=$ Hedonic consumption behavior exhibits significant differences from consumer demographics point of view

\section{Analyses and Results}

Hypotheses Tests Results

Bi-variate analysis of test results proved strong relationships between fashion involvement and personal traits at $\square<0.01$ significance level as shown on the following table:

Table 2. Relationship Between Fashion Involvement and Personal Traits

\begin{tabular}{|c|c|c|c|c|c|c|c|c|c|}
\hline \multirow{2}{*}{\begin{tabular}{l|} 
Fashion Involvement \\
Statement
\end{tabular}} & \multicolumn{3}{|c|}{$\begin{array}{l}\text { Brand } \\
\text { Loyalty }\end{array}$} & \multicolumn{3}{|c|}{$\begin{array}{l}\text { Innovative } \\
\text { ness }\end{array}$} & \multicolumn{3}{|c|}{$\begin{array}{l}\text { Opinion } \\
\text { Leaders } \\
\text { hip }\end{array}$} \\
\hline & A & B & C & A & D & $E$ & A & $F$ & $\mathbf{G}$ \\
\hline $\begin{array}{l}\text { I usually dress for fashion,; } \\
\text { comfort is only of secodary } \\
\text { importance to me. }\end{array}$ & $\begin{array}{l}15 \\
.0\end{array}$ & $\begin{array}{l}44 \\
.2\end{array}$ & 6.0 & $\begin{array}{l}15 . \\
0\end{array}$ & $\begin{array}{l}55 . \\
0\end{array}$ & 4.7 & 15.0 & $\begin{array}{l}54 \\
.4\end{array}$ & 4.3 \\
\hline $\begin{array}{l}\text { I am interested in shopping at } \\
\text { boutique or fashion specialty } \\
\text { stores rather than at department } \\
\text { stores or other discount stores }\end{array}$ & $\begin{array}{l}24 \\
.5\end{array}$ & $\begin{array}{l}55 \\
.9\end{array}$ & 8.7 & $\begin{array}{l}24 . \\
5\end{array}$ & 3 & 6.3 & 24.5 & $\begin{array}{l}67 \\
.4\end{array}$ & 7.3 \\
\hline $\begin{array}{l}\text { Dressing smartly is a philosophy } \\
\text { in my life }\end{array}$ & $\begin{array}{l}40 \\
.2\end{array}$ & $\begin{array}{l}77 \\
.9\end{array}$ & $\begin{array}{l}26 . \\
1\end{array}$ & \begin{tabular}{|l}
40. \\
2
\end{tabular} & $\begin{array}{l}83 . \\
4\end{array}$ & 13.7 & 40.2 & $\begin{array}{l}87 \\
.0\end{array}$ & 15.4 \\
\hline $\begin{array}{l}\text { Fashion does not mean spending } \\
\text { extravagantly I can also get } \\
\text { fashion goods without spending a }\end{array}$ & $\begin{array}{l}68 \\
.1\end{array}$ & $\begin{array}{l}49 \\
.4 \\
(*)\end{array}$ & $\begin{array}{l}76 . \\
1\end{array}$ & $\begin{array}{l}68 . \\
1\end{array}$ & $\begin{array}{l}33 . \\
4 \\
\left({ }^{*}\right)\end{array}$ & 78.4 & 68.1 & $\begin{array}{l}30 \\
.4\end{array}$ & 77.4 \\
\hline
\end{tabular}




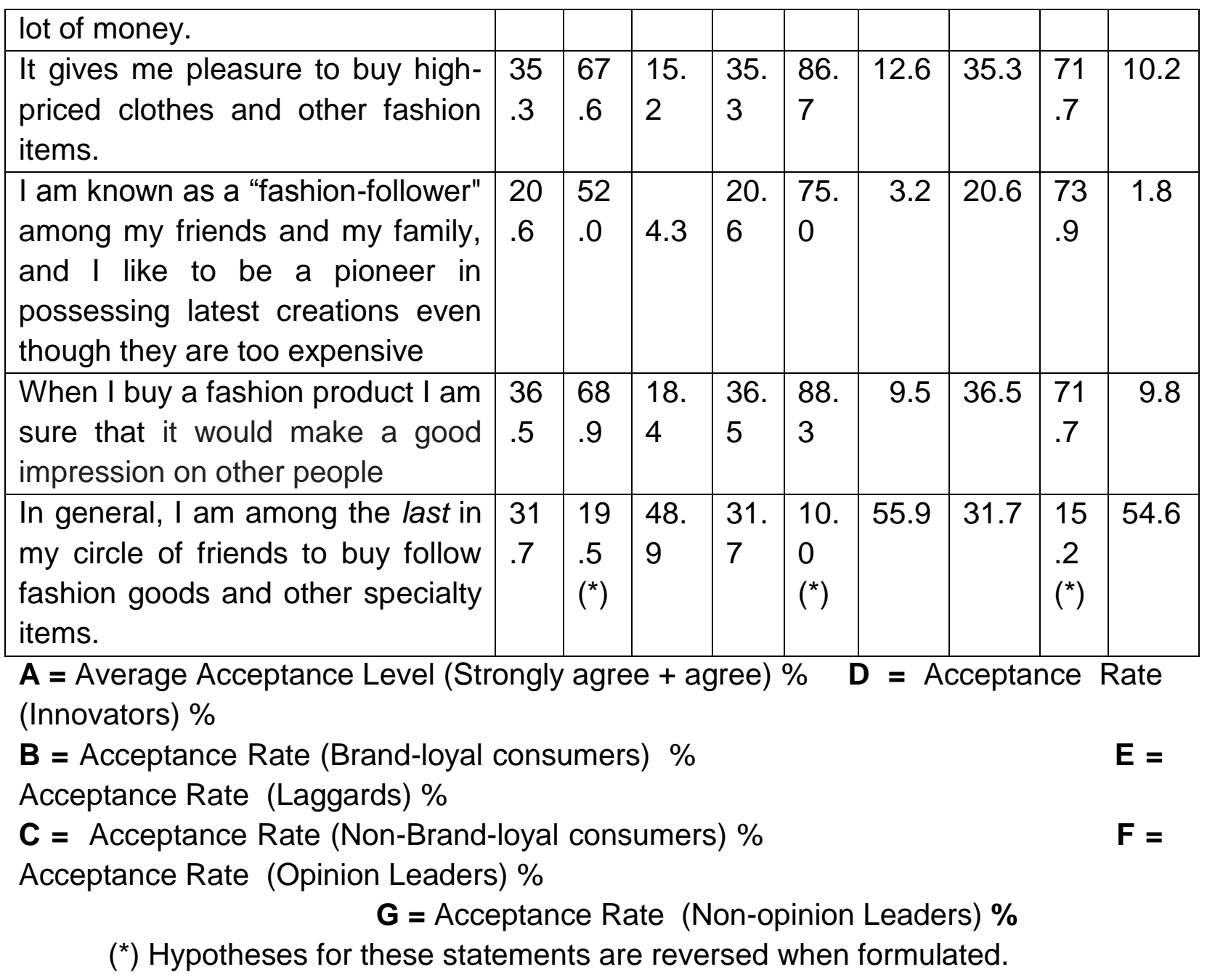

The values on the above table reveals clearly that all eight hypotheses of the first group are accepted at $\square<0.01$ significance level and consumer groups as innovators, innovators and opinion leaders are highly involved in fashion products.

The second group of hypotheses which are formulated to test the relationship between materialistic urges and compulsive buying behavior is sustained at all levels on a $\square<0.01$ significance level (except one level) as follows:

Table 3. Relationship Between Materialism and Compulsive Buying Behavior.

\begin{tabular}{|c|c|c|c|c|c|c|c|c|c|}
\hline Materialistic Behavior & & \multicolumn{2}{|c|}{$\begin{array}{l}\text { Impatie } \\
\text { nce }\end{array}$} & \multicolumn{3}{|c|}{$\begin{array}{l}\text { Excitemen } \\
t\end{array}$} & \multicolumn{3}{|c|}{$\begin{array}{l}\text { Impressi } \\
\text { on }\end{array}$} \\
\hline Statement & $\mathbf{A}$ & B & $\mathbf{C}$ & A & $\mathbf{D}$ & $\mathbf{E}$ & A & $\mathbf{F}$ & $\mathbf{G}$ \\
\hline $\begin{array}{l}\text { I admire and envy people who } \\
\text { own expensive and luxurious } \\
\text { possessions such as cars, } \\
\text { mansions, clothing, accessories, } \\
\text { electronics etc. }\end{array}$ & $\begin{array}{l}23 \\
.6\end{array}$ & $\begin{array}{l}35 \\
.3\end{array}$ & $\begin{array}{l}14 . \\
9\end{array}$ & $\begin{array}{l}23 . \\
6\end{array}$ & $\begin{array}{l}35 . \\
2\end{array}$ & 7.5 & 23.6 & $\begin{array}{l}36 \\
.7\end{array}$ & 5.1 \\
\hline I don't pay attention and develop & 53 & 39 & & 53. & 46. & 60.7 & 53.3 & 42 & 51.7 \\
\hline
\end{tabular}




\begin{tabular}{|l|l|l|l|l|l|l|l|l|l|}
\hline $\begin{array}{l}\text { interest to the material } \\
\text { possessions of the other people. }\end{array}$ & .3 & $\begin{array}{l}.5 \\
\left({ }^{*}\right)\end{array}$ & $\begin{array}{l}56 . \\
5\end{array}$ & 3 & $\begin{array}{l}9 \\
\left({ }^{*}\right)\end{array}$ & & & $\begin{array}{l}.2 \\
(*)\end{array}$ & \\
\hline $\begin{array}{l}\text { I like to have a lot of luxury in my } \\
\text { life. }\end{array}$ & $\begin{array}{l}78 \\
.5\end{array}$ & $\begin{array}{l}72.8 \\
.8\end{array}$ & $\begin{array}{l}49 . \\
4\end{array}$ & $\begin{array}{l}65 . \\
5\end{array}$ & 34.0 & 48.4 & 69 & 34.5 \\
\hline I could have lead a better life if I & 34 & 53 & & 34. & 40. & 19.2 & 34.8 & 52 & 25.9 \\
$\begin{array}{l}\text { owned more luxurious items that I } \\
\text { don't currently have }\end{array}$ & .8 & .8 & $\begin{array}{l}21 . \\
6\end{array}$ & 8 & $\begin{array}{l}7 \\
\left({ }^{* *}\right)\end{array}$ & & & .3 & \\
\hline
\end{tabular}

$\mathbf{A}=$ Average Acceptance Level (Strongly agree + agree) $\% \quad \mathbf{D}=$ Acceptance Rate (Excited) \%

B = Acceptance Rate (Impatient) \%

$\mathbf{E}=$ Acceptance

Rate (Not Excited) \%

$\mathbf{C}=$ Acceptance Rate (Patient) \% $\quad \mathbf{F}=$ Acceptance Rate (Impressed) \%

$\mathbf{G}=$ Acceptance Rate (Not impressed) \%

$\left(^{*}\right)$ Hypotheses for these statements are reversed when formulated.

$\left({ }^{* *}\right)$ Sustained at $\square<0.05$ significance level

The hypotheses formulated between price insensitivity and some personality traits yielded the following results $\left({ }^{*}\right)$ :

Table 4. Relationship Between Price Insensitivity and Some Personality Traits.

\begin{tabular}{|c|c|c|c|c|c|c|c|c|c|}
\hline Personality Traits & & $\begin{array}{l}\text { FEEL } \\
\text { ST }\end{array}$ & & & $\mathrm{HOC}$ & SEX & & $\begin{array}{l}\text { RTH } \\
\text { R }\end{array}$ & \\
\hline Statement & A & B & C & A & D & $E$ & A & $F$ & $\mathbf{G}$ \\
\hline $\begin{array}{l}\text { I believe that some of the } \\
\text { specialty items I buy would } \\
\text { impress other people. }\end{array}$ & $\begin{array}{l}27 \\
.6\end{array}$ & $\begin{array}{l}62 \\
.3\end{array}$ & \begin{tabular}{|l|}
0.0 \\
0
\end{tabular} & $\begin{array}{l}20 . \\
7\end{array}$ & $\begin{array}{l}38 . \\
5\end{array}$ & 5.7 & 44.2 & $\begin{array}{l}83 \\
.8\end{array}$ & 21.1 \\
\hline $\begin{array}{l}\text { fancy the prestige that is } \\
\text { accompanied with a high priced } \\
\text { product }\end{array}$ & $\begin{array}{l}27 \\
.6\end{array}$ & $\begin{array}{l}63 \\
.9\end{array}$ & 4.2 & $\begin{array}{l}20 . \\
7\end{array}$ & $\begin{array}{l}48 . \\
4\end{array}$ & 7.8 & 44.2 & $\begin{array}{l}86 \\
.6\end{array}$ & 17.4 \\
\hline $\begin{array}{l}\text { I believe other people judge my } \\
\text { personality with respect to the } \\
\text { type and brand of the specialty } \\
\text { items that I use. }\end{array}$ & $\begin{array}{l}27 \\
.6\end{array}$ & $\begin{array}{l}61 \\
.2\end{array}$ & 7.1 & $\begin{array}{l}20 . \\
7\end{array}$ & $\begin{array}{l}40 . \\
3\end{array}$ & 8.6 & 44.2 & $\begin{array}{l}65 \\
.7\end{array}$ & 25.0 \\
\hline $\begin{array}{l}\text { A product which has snob appeal } \\
\text { is more valuable to me. }\end{array}$ & $\begin{array}{l}27 \\
.6\end{array}$ & $\begin{array}{l}68 \\
.9\end{array}$ & 7.0 & $\begin{array}{l}20 . \\
7\end{array}$ & $\begin{array}{l}42 . \\
7\end{array}$ & 9.5 & 44.2 & $\begin{array}{l}85 \\
.5\end{array}$ & 24.4 \\
\hline
\end{tabular}

\begin{tabular}{|l|l|}
\hline FEELDIST & $\begin{array}{l}\text { Buying the most expensive brand of a fashion product } \\
\text { makes me feel distinguished. }\end{array}$ \\
\hline $\begin{array}{l}\text { CHOOSEX } \\
\mathbf{P}\end{array}$ & $\begin{array}{l}\text { I feel it is mpressive to choose a relatively more } \\
\text { expensive fashion product even a cheaper equivalent is } \\
\text { available in the stores. }\end{array}$ \\
\hline WRTHPAY & Real good clothing and other valuable specialty items are \\
\hline
\end{tabular}



worth paying a lot of money for.

$\mathbf{A}=$ Average Acceptance Level (Strongly agree + agree) $\% \quad \mathbf{D}=$ Acceptance Rate (Feel Impressive) \%

$\mathbf{B}=$ Acceptance Rate (Feel Distinguished) \% $\quad$ E = Acceptance Rate (Feel Unimpressive) \%

C = Acceptance Rate (Feel Indifferent) \%

$\mathbf{F}=$ Acceptance Rate Worth Paying) \%

$$
\text { G = Acceptance Rate (Not Worth Paying) \% }
$$

$\left.{ }^{*}\right)$ All hypotheses are sustained at $\square<0.05$ significance level

Table 5. Relationship Between Hedonic Consumption Behavior and Consumer Demographics

\begin{tabular}{|c|c|c|c|c|c|}
\hline & \multicolumn{5}{|c|}{ Consumer Demographics } \\
\hline Statements & Age & Gender & Occupation & Education & Income \\
\hline $\begin{array}{l}\text { I usually dress for } \\
\text { fashion,; comfort is } \\
\text { only of secodary } \\
\text { importance to me. }\end{array}$ & Rejected & Rejected & $\begin{array}{l}\text { Self- } \\
\text { employed } \\
(23.6 \%)\end{array}$ & $\begin{array}{l}\text { Univers- } \\
\text { ity } \\
(18.5 \%)\end{array}$ & $\begin{array}{l}+\$ 3.600 \\
(33.3 \%)\end{array}$ \\
\hline $\begin{array}{l}\text { I am interested in } \\
\text { shopping at boutique } \\
\text { or fashion specialty } \\
\text { stores rather than at } \\
\text { department stores or } \\
\text { other discount stores }\end{array}$ & Rejected & $\begin{array}{l}\text { Females } \\
(29.4 \%)\end{array}$ & $\begin{array}{l}\text { Self- } \\
\text { employed } \\
(41.0 \%)\end{array}$ & $\begin{array}{l}\text { Univers- } \\
\text { ity } \\
(29.8 \%)\end{array}$ & $\begin{array}{l}+\$ 3.600 \\
(51.1 \%)\end{array}$ \\
\hline $\begin{array}{l}\text { Dressing smartly is a } \\
\text { philosophy in my life }\end{array}$ & $\begin{array}{c}26-40 \\
(43.8 \%) \\
\end{array}$ & $\begin{array}{l}\text { Females } \\
(42.4 \%)\end{array}$ & $\begin{array}{l}\text { Self- } \\
\text { employed } \\
(57.7 \%)\end{array}$ & $\begin{array}{l}\text { Univers- } \\
\text { ity } \\
(46.6 \%)\end{array}$ & $\begin{array}{l}+\$ 3.600 \\
(57.8 \%)\end{array}$ \\
\hline $\begin{array}{l}\text { It gives me pleasure to } \\
\text { buy high-priced } \\
\text { clothes and other } \\
\text { fashion items. }\end{array}$ & $\begin{array}{r}26-40 \\
(41.5 \%)\end{array}$ & $\begin{array}{l}\text { Females } \\
(42.8 \%)\end{array}$ & $\begin{array}{l}\text { Self- } \\
\text { employed } \\
(46.2 \%)\end{array}$ & $\begin{array}{l}\text { Univers- } \\
\text { ity } \\
(41.0 \%)\end{array}$ & $\begin{array}{l}+\$ 3.600 \\
(59.8 \%)\end{array}$ \\
\hline $\begin{array}{l}\text { I am known as a } \\
\text { "fashion-follower" } \\
\text { among my friends and } \\
\text { my family, and I like to } \\
\text { be a pioneer in } \\
\text { possessing latest } \\
\text { creations even though } \\
\text { they are too expensive }\end{array}$ & $\begin{array}{r}26-40 \\
(24.9 \%)\end{array}$ & $\begin{array}{c}\text { Females } \\
(23.8 \%) \\
\left({ }^{*}\right)\end{array}$ & $\begin{array}{l}\text { Self- } \\
\text { employed } \\
(34.9 \%)\end{array}$ & $\begin{array}{l}\text { Univers- } \\
\text { ity } \\
(26.2 \%)\end{array}$ & $\begin{array}{l}+\$ 3.600 \\
(48.8 \%)\end{array}$ \\
\hline $\begin{array}{l}\text { When I buy a fashion } \\
\text { product I am sure that }\end{array}$ & $26-40$ & Rejected & $\begin{array}{l}\text { Self- } \\
\text { employed }\end{array}$ & $\begin{array}{l}\text { Univers- } \\
\text { ity }\end{array}$ & $\begin{array}{l}+\$ 3.600 \\
(60.0 \%)\end{array}$ \\
\hline
\end{tabular}




\begin{tabular}{|c|c|c|c|c|c|}
\hline $\begin{array}{l}\text { it would make a good } \\
\text { impression on other } \\
\text { people }\end{array}$ & $(45.5 \%)$ & & $(47.1 \%)$ & $(41.1 \%)$ & \\
\hline $\begin{array}{l}\text { b-Price } \\
\text { (in)Sensitivity }\end{array}$ & Age & Gender & Occupation & Education & Income \\
\hline $\begin{array}{l}\text { Buying the most } \\
\text { expensive brand of a } \\
\text { fashion product makes } \\
\text { me feel distinguished. }\end{array}$ & $\begin{array}{c}26-40 \\
(35.2 \%)\end{array}$ & $\begin{array}{l}\text { Females } \\
(34.1 \%)\end{array}$ & $\begin{array}{l}\text { Self- } \\
\text { employed } \\
(37.7 \%)\end{array}$ & $\begin{array}{l}\text { Univers- } \\
\text { ity } \\
(32.3 \%)\end{array}$ & $\begin{array}{l}+\$ 3.600 \\
(51.1 \%)\end{array}$ \\
\hline $\begin{array}{l}\text { I feel it is impressive } \\
\text { to choose a relatively } \\
\text { more expensive } \\
\text { fashion product even } \\
\text { a cheaper equivalent } \\
\text { is available in the } \\
\text { stores. }\end{array}$ & $\begin{array}{c}26-40 \\
(25.5 \%)\end{array}$ & $\begin{array}{l}\text { Females } \\
(22.9 \%)\end{array}$ & $\begin{array}{l}\text { Self- } \\
\text { employed } \\
(33.5 \%)\end{array}$ & $\begin{array}{l}\text { Univers- } \\
\text { ity } \\
(23.9 \%)\end{array}$ & $\begin{array}{l}+\$ 3.600 \\
(44.5 \%)\end{array}$ \\
\hline $\begin{array}{l}\text { Real good clothing } \\
\text { and other valuable } \\
\text { specialty items are } \\
\text { worth paying a lot of } \\
\text { money for. }\end{array}$ & $\begin{array}{c}18-25 \\
(47.3 \%)\end{array}$ & Rejected & $\begin{array}{l}\text { Self- } \\
\text { employed } \\
(54.2 \%)\end{array}$ & $\begin{array}{l}\text { Univers- } \\
\text { ity } \\
(50.7 \%)\end{array}$ & $\begin{array}{l}+\$ 3.600 \\
(71.1 \%)\end{array}$ \\
\hline $\begin{array}{l}\text { If I constantly search } \\
\text { for cheap items, other } \\
\text { people will think of me } \\
\text { as a stingy person. }\end{array}$ & Rejected & Rejected & $\begin{array}{c}\text { Businessman } \\
(39.4 \%)\end{array}$ & $\begin{array}{l}\text { High- } \\
\text { School } \\
(31.8 \%) \\
\left({ }^{*}\right)\end{array}$ & $\begin{array}{l}+\$ 3.600 \\
(47.9 \%)\end{array}$ \\
\hline $\begin{array}{l}\text { c- Hedonic } \\
\text { Consumer } \\
\text { Characteristics }\end{array}$ & Age & Gender & Occ & Education & Income \\
\hline $\begin{array}{l}\text { I think I am impatient } \\
\text { - If I want to possess } \\
\text { something I buy it } \\
\text { readily and quickly }\end{array}$ & $\begin{array}{c}18-25 \\
(45.7 \%)\end{array}$ & Rejected & $\begin{array}{l}\text { Self- } \\
\text { employed } \\
(46.4 \%)\end{array}$ & $\begin{array}{l}\text { Univers- } \\
\text { ity } \\
(40.2 \%)\end{array}$ & $\begin{array}{l}+\$ 3.600 \\
(55.5 \%)\end{array}$ \\
\hline $\begin{array}{lr}\text { Excitement } & \text { and } \\
\text { adventures } & \text { is } \\
\text { indispensable part of } \\
\text { my life }\end{array}$ & $\begin{array}{c}18-25 \\
(59.8 \%)\end{array}$ & $\begin{array}{l}\text { Males } \\
(47.7 \%)\end{array}$ & $\begin{array}{l}\text { Self- } \\
\text { employed } \\
(56.1 \%)\end{array}$ & $\begin{array}{l}\text { Univers- } \\
\text { ity } \\
(48.2 \%)\end{array}$ & $\begin{array}{l}\$ 1801- \\
3600 \\
(58.1 \%)\end{array}$ \\
\hline $\begin{array}{l}\text { search for strong } \\
\text { impressions and } \\
\text { experiences in my free } \\
\text { time, they help me to } \\
\text { loosen from everyday } \\
\text { life }\end{array}$ & $\begin{array}{c}26-40 \\
(57.7 \%)\end{array}$ & Rejected & $\begin{array}{l}\text { Self- } \\
\text { employed } \\
(65.6 \%)\end{array}$ & $\begin{array}{l}\text { Univers- } \\
\text { ity } \\
(58.2 \%)\end{array}$ & $\begin{array}{l}\$ 1801- \\
3600 \\
(68.4 \%)\end{array}$ \\
\hline I want to emphasize & $26-40$ & Rejected & Self- & Univers- & $+\$ 3.600$ \\
\hline
\end{tabular}




\begin{tabular}{|c|c|c|c|c|c|}
\hline $\begin{array}{l}\text { certain features of my } \\
\text { personality by } \\
\text { distinguished services } \\
\text { that I use }\end{array}$ & $(48.0 \%)$ & & $\begin{array}{l}\text { employed } \\
(54.7 \%)\end{array}$ & $\begin{array}{l}\text { ity } \\
(44.3 \%)\end{array}$ & (64.4\%) \\
\hline $\begin{array}{l}\text { Using fashion goods } \\
\text { and leading my life in } \\
\text { luxury gives a modern } \\
\text { impression of myself } \\
\text { to other people. }\end{array}$ & $\begin{array}{c}26-40 \\
(40.9 \%)\end{array}$ & $\begin{array}{l}\text { Females } \\
(41.7 \%)\end{array}$ & $\begin{array}{l}\text { Self- } \\
\text { employed } \\
(43.8 \%)\end{array}$ & $\begin{array}{l}\text { Univers- } \\
\text { ity } \\
(37.4 \%) \\
\left({ }^{*}\right)\end{array}$ & $\begin{array}{l}+\$ 3.600 \\
(64.5 \%)\end{array}$ \\
\hline $\begin{array}{l}\text { Visiting fashion malls } \\
\text { and other specialty } \\
\text { stores is quite a } \\
\text { pleasure for me. }\end{array}$ & $\begin{array}{c}26-40 \\
(38.2 \%)\end{array}$ & $\begin{array}{l}\text { Females } \\
(46.7 \%)\end{array}$ & $\begin{array}{l}\text { Self- } \\
\text { employed } \\
(42.0 \%)\end{array}$ & $\begin{array}{l}\text { Univers- } \\
\text { ity } \\
(38.7 \%)\end{array}$ & $\begin{array}{l}+\$ 3.600 \\
(62.2 \%)\end{array}$ \\
\hline $\begin{array}{l}\text { d- } \\
\text { Orientation }\end{array}$ & Age & Gender & Occupation & Education & Income \\
\hline $\begin{array}{l}\text { I prefer fancy } \\
\text { (expensive) } \\
\text { restaurants and other } \\
\text { amusement places } \\
\text { where the weight is } \\
\text { given to factors } \\
\text { ambience, food and } \\
\text { service }\end{array}$ & $\begin{array}{l}26-40 \\
(33.0 \%)\end{array}$ & $\begin{array}{l}\text { Females } \\
(31.9 \%)\end{array}$ & $\begin{array}{l}\text { Self- } \\
\text { employed } \\
(46.7 \%)\end{array}$ & $\begin{array}{l}\text { Univers- } \\
\text { ity } \\
(36.6 \%)\end{array}$ & $\begin{array}{l}+\$ 3.600 \\
(57.8 \%)\end{array}$ \\
\hline $\begin{array}{l}\text { I deserve relaxation as } \\
\text { a reward for my daily } \\
\text { effort }\end{array}$ & $\begin{array}{l}26-40 \\
(89.7 \%)\end{array}$ & Rejected & $\begin{array}{l}\text { Businessman } \\
(91.5 \%)\end{array}$ & Rejected & $\begin{array}{l}\$ 901- \\
1800 \\
(87.5 \%) \\
\left({ }^{*}\right)\end{array}$ \\
\hline $\begin{array}{l}\text { rate fashion goods, } \\
\text { expensive food, drinks } \\
\text { and traveling as ten } \\
\text { basic truths of my life }\end{array}$ & $\begin{array}{c}26-40 \\
(26.6 \%)\end{array}$ & $\begin{array}{l}\text { Females } \\
(26.7 \%) \\
\left({ }^{*}\right)\end{array}$ & $\begin{array}{l}\text { Self- } \\
\text { employed } \\
(35.4 \%)\end{array}$ & $\begin{array}{l}\text { Univers- } \\
\text { ity } \\
(25.3 \%)\end{array}$ & $\begin{array}{l}+\$ 3.600 \\
(55.6 \%)\end{array}$ \\
\hline $\begin{array}{l}\text { Expensive and high } \\
\text { quality goods and } \\
\text { services help me the } \\
\text { type of life I strive for. }\end{array}$ & $\begin{array}{l}26-40 \\
(40.1 \%)\end{array}$ & Rejected & $\begin{array}{l}\text { Self- } \\
\text { employed } \\
(47.6 \%)\end{array}$ & $\begin{array}{l}\text { Univers- } \\
\text { ity } \\
(36.7 \%)\end{array}$ & $\begin{array}{l}+\$ 3.600 \\
(77.8 \%)\end{array}$ \\
\hline $\begin{array}{l}\text { Using specialty items } \\
\text { help me to behave in } \\
\text { the manner which I } \\
\text { like to behave }\end{array}$ & Rejected & Rejected & $\begin{array}{l}\text { Self- } \\
\text { employed } \\
(45.9 \%)\end{array}$ & $\begin{array}{l}\text { Univers- } \\
\text { ity } \\
(34.0 \%) \\
\left({ }^{*}\right)\end{array}$ & $\begin{array}{l}+\$ 3.600 \\
(60.0 \%)\end{array}$ \\
\hline $\begin{array}{l}\text { If I could not find my } \\
\text { preferred brand of the } \\
\text { specialty item, I can } \\
\text { switch to another }\end{array}$ & $\begin{array}{l}41-62 \\
(40.1 \%)\end{array}$ & Rejected & $\begin{array}{l}\text { House- } \\
\text { Wife } \\
(74.0 \%)\end{array}$ & $\begin{array}{l}\text { High- } \\
\text { School } \\
(71.7 \%)\end{array}$ & $\begin{array}{c}\$ 0-450 \\
(77.1)\end{array}$ \\
\hline
\end{tabular}




\begin{tabular}{|c|c|c|c|c|c|}
\hline $\begin{array}{l}\text { brand provided that it } \\
\text { possesses more or } \\
\text { less the same } \\
\text { features. }\end{array}$ & & & & & \\
\hline $\begin{array}{l}\text { I feel I if I had given a } \\
\text { present or a reward to } \\
\text { myself whenever I buy } \\
\text { expensive cosmetics. }\end{array}$ & $\begin{array}{l}26-40 \\
(42.3 \%)\end{array}$ & $\begin{array}{l}\text { Females } \\
(46.0 \%)\end{array}$ & $\begin{array}{l}\text { House- } \\
\text { Wife } \\
(49.0 \%)\end{array}$ & $\begin{array}{l}\text { Univers- } \\
\text { ity } \\
(41.2 \%)\end{array}$ & $\begin{array}{l}\$ 1801- \\
3600 \\
(50.4 \%)\end{array}$ \\
\hline $\begin{array}{l}\text { e- Brand Loyalty } \& \\
\text { Innovativeness } \quad \& \\
\text { Opinion leadership }\end{array}$ & Age & Gender & Occupation & Education & Income \\
\hline $\begin{array}{l}\text { If my preferred brand } \\
\text { of a specialty item } \\
\text { were not available at } \\
\text { the store, I would shop } \\
\text { at other stores until I } \\
\text { found my brand. }\end{array}$ & $\begin{array}{l}26-40 \\
(33.9 \%)\end{array}$ & Rejected & $\begin{array}{l}\text { Self- } \\
\text { employed } \\
(40.1 \%)\end{array}$ & $\begin{array}{l}\text { Univers- } \\
\text { ity } \\
(33.2 \%)\end{array}$ & $\begin{array}{l}+\$ 3.600 \\
(51.2 \%)\end{array}$ \\
\hline $\begin{array}{l}\text { l know more about } \\
\text { new fashions and } \\
\text { other expensive } \\
\text { novelties before other } \\
\text { people do. }\end{array}$ & $\begin{array}{l}26-40 \\
(40.7 \%)\end{array}$ & $\begin{array}{l}\text { Females } \\
(24.6 \%)\end{array}$ & $\begin{array}{l}\text { Self- } \\
\text { employed } \\
(35.3 \%)\end{array}$ & $\begin{array}{l}\text { Univers- } \\
\text { ity } \\
(28.0 \%)\end{array}$ & $\begin{array}{l}+\$ 3.600 \\
(48.9 \%)\end{array}$ \\
\hline $\begin{array}{l}\text { I can classify myself } \\
\text { as an expert on } \\
\text { fashion clothing. }\end{array}$ & $\begin{array}{l}26-40 \\
(24.3 \%)\end{array}$ & $\begin{array}{l}\text { Females } \\
(24.6 \%)\end{array}$ & $\begin{array}{l}\text { Self- } \\
\text { employed } \\
(36.3 \%)\end{array}$ & $\begin{array}{l}\text { Univers- } \\
\text { ity } \\
(25.6 \%)\end{array}$ & $\begin{array}{l}+\$ 3.600 \\
(53.3 \%)\end{array}$ \\
\hline f- Personality & Age & Gender & Occupation & Education & Income \\
\hline $\begin{array}{l}\text { I believe that some of } \\
\text { the specialty items I } \\
\text { buy would impress } \\
\text { other people. }\end{array}$ & $\begin{array}{l}18-25 \\
(59.4 \%)\end{array}$ & Rejected & $\begin{array}{l}\text { Self- } \\
\text { employed } \\
(61.8 \%)\end{array}$ & $\begin{array}{l}\text { Univers- } \\
\text { ity } \\
(60.0 \%)\end{array}$ & $\begin{array}{l}\$ 1801- \\
3600 \\
(72.1 \%)\end{array}$ \\
\hline $\begin{array}{l}\text { I fancy the prestige } \\
\text { that is accompanied } \\
\text { with a high priced } \\
\text { product }\end{array}$ & $\begin{array}{r}26-40 \\
(41.4 \%)\end{array}$ & $\begin{array}{l}\text { Females } \\
(40.6 \%) \\
\left({ }^{*}\right)\end{array}$ & $\begin{array}{l}\text { Businessman } \\
(40.5 \%)\end{array}$ & $\begin{array}{l}\text { Univers- } \\
\text { ity } \\
(40.3 \%)\end{array}$ & $\begin{array}{l}+\$ 3.600 \\
(55.6 \%)\end{array}$ \\
\hline $\begin{array}{l}\text { I believe other people } \\
\text { judge my personality } \\
\text { with respect to the } \\
\text { type and brand of the } \\
\text { specialty items that I } \\
\text { use. }\end{array}$ & $\begin{array}{r}26-40 \\
(36.0 \%)\end{array}$ & $\begin{array}{l}\text { Females } \\
(31.2 \%)\end{array}$ & $\begin{array}{l}\text { Self- } \\
\text { employed } \\
(42.0 \%)\end{array}$ & $\begin{array}{l}\text { Univers- } \\
\text { ity } \\
(28.4 \%) \\
\left({ }^{*}\right)\end{array}$ & $\begin{array}{l}+\$ 3.600 \\
(53.3 \%)\end{array}$ \\
\hline $\begin{array}{l}\text { My greatest dream in } \\
\text { life is to possess }\end{array}$ & $\begin{array}{r}26-40 \\
(24.4 \%)\end{array}$ & Rejected & $\begin{array}{l}\text { Self- } \\
\text { employed }\end{array}$ & $\begin{array}{l}\text { Univers- } \\
\text { ity }\end{array}$ & $\begin{array}{l}+\$ 3.600 \\
(46.7 \%)\end{array}$ \\
\hline
\end{tabular}




\begin{tabular}{|c|c|c|c|c|c|}
\hline something expensive & & & $(31.1 \%)$ & $(22.7 \%)$ & \\
\hline $\begin{array}{l}\text { A product which has } \\
\text { snob appeal is more } \\
\text { valuable to me. }\end{array}$ & Rejected & Rejected & $\begin{array}{l}\text { Self- } \\
\text { employed } \\
(39.2 \%)\end{array}$ & $\begin{array}{l}\text { Univers- } \\
\text { ity } \\
(32.5 \%)\end{array}$ & $\begin{array}{l}\$ 1801- \\
3600 \\
(48.8 \%)\end{array}$ \\
\hline g- Materialism & Age & Gender & Occupation & Education & Income \\
\hline $\begin{array}{l}\text { I admire and envy } \\
\text { people who own } \\
\text { expensive and } \\
\text { luxurious possessions } \\
\text { such as cars, } \\
\text { mansions, clothing, } \\
\text { accessories, } \\
\text { electronics etc. }\end{array}$ & Rejected & Rejected & $\begin{array}{l}\text { Businessman } \\
(29.8 \%) \\
\left({ }^{*}\right)\end{array}$ & Rejected & $\begin{array}{l}+\$ 3.600 \\
(35.5 \%)\end{array}$ \\
\hline $\begin{array}{l}\text { I don't pay attention } \\
\text { and develop interest } \\
\text { to the material } \\
\text { possessions of the } \\
\text { other people. }\end{array}$ & $\begin{array}{r}41-62 \\
(60.5 \%)\end{array}$ & Rejected & $\begin{array}{l}\text { House- } \\
\text { Wife } \\
(62.0 \%)\end{array}$ & Rejected & $\begin{array}{l}\$ 451- \\
900 \\
(61.1)\end{array}$ \\
\hline $\begin{array}{l}\text { I like to have a lot of } \\
\text { luxury in my life. }\end{array}$ & $\begin{array}{r}26-40 \\
(55.5 \%)\end{array}$ & $\begin{array}{l}\text { Females } \\
(54.6 \%)\end{array}$ & $\begin{array}{c}\text { Businessman } \\
(62.8 \%)\end{array}$ & $\begin{array}{l}\text { Univers- } \\
\text { ity } \\
(53.1 \%)\end{array}$ & $\begin{array}{l}+\$ 3.600 \\
(66.7 \%)\end{array}$ \\
\hline $\begin{array}{l}\text { I could have lead a } \\
\text { better life if I owned } \\
\text { more luxurious items } \\
\text { that I don't currently } \\
\text { have }\end{array}$ & $\begin{array}{r}26-40 \\
(42.4 \%)\end{array}$ & Rejected & Rejected & Rejected & $\begin{array}{c}+\$ 3.600 \\
(51.2 \%) \\
\left(^{*}\right)\end{array}$ \\
\hline
\end{tabular}

$\left(^{*}\right)$ Accepted at $\square<0.05$ significance level

Table 6. Factor Analysis Results

Rotated Component Matrix(a)

\begin{tabular}{|c|c|c|c|c|c|c|}
\hline & \multicolumn{6}{|c|}{ Component } \\
\hline & 1 & 2 & 3 & 4 & 5 & 6 \\
\hline $\begin{array}{l}\text { I can classify myself } \\
\text { as an expert on } \\
\text { fashion clothing }\end{array}$ & ,702 & 202 & , 071 & 211 & ,075 &,- 167 \\
\hline $\begin{array}{l}\text { I know more about } \\
\text { new fashions and } \\
\text { other expensive } \\
\text { novelties before } \\
\text { other people do }\end{array}$ & ,685 & 199 & 189 & 291, & 138 &,- 151 \\
\hline
\end{tabular}




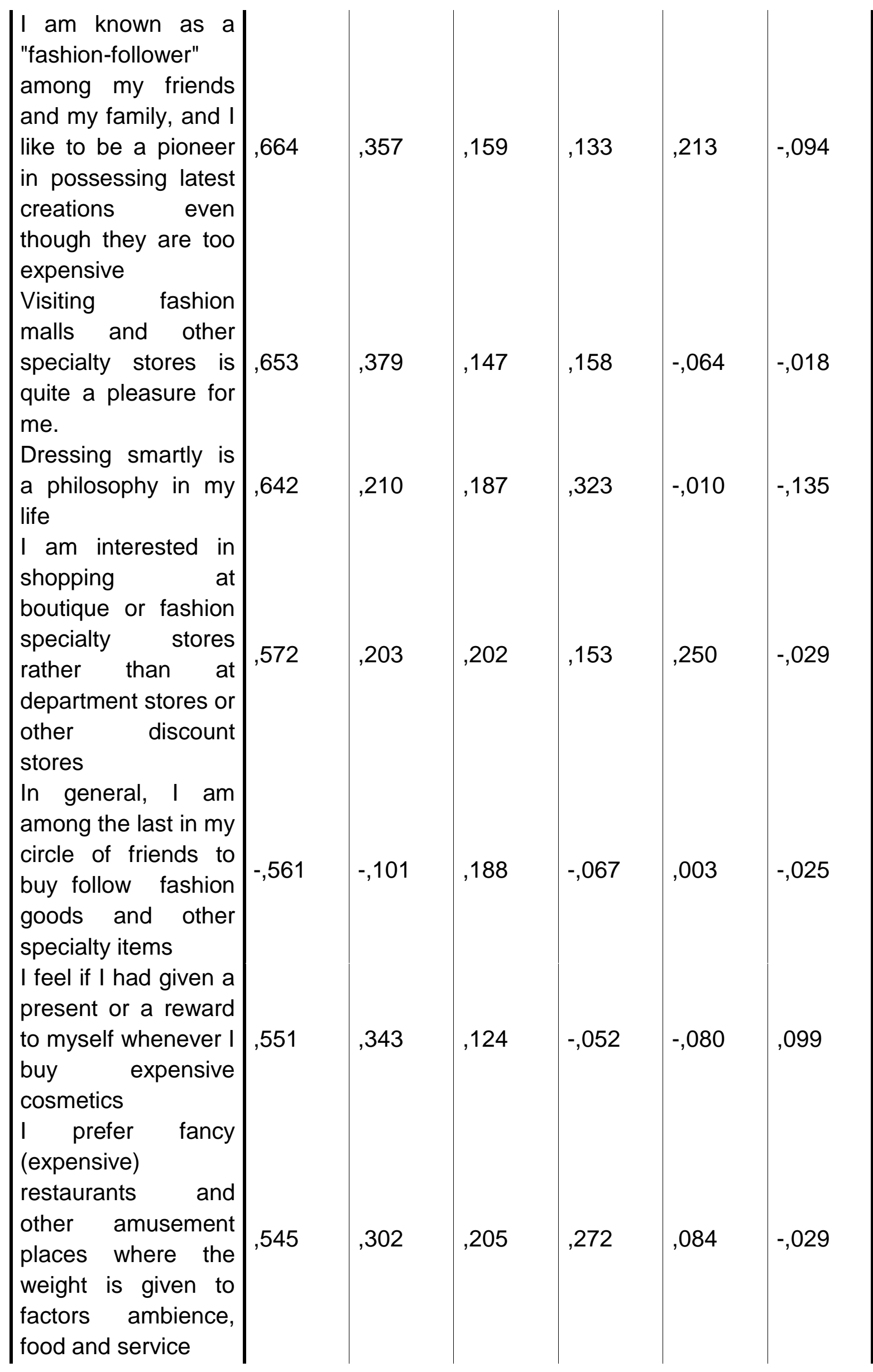




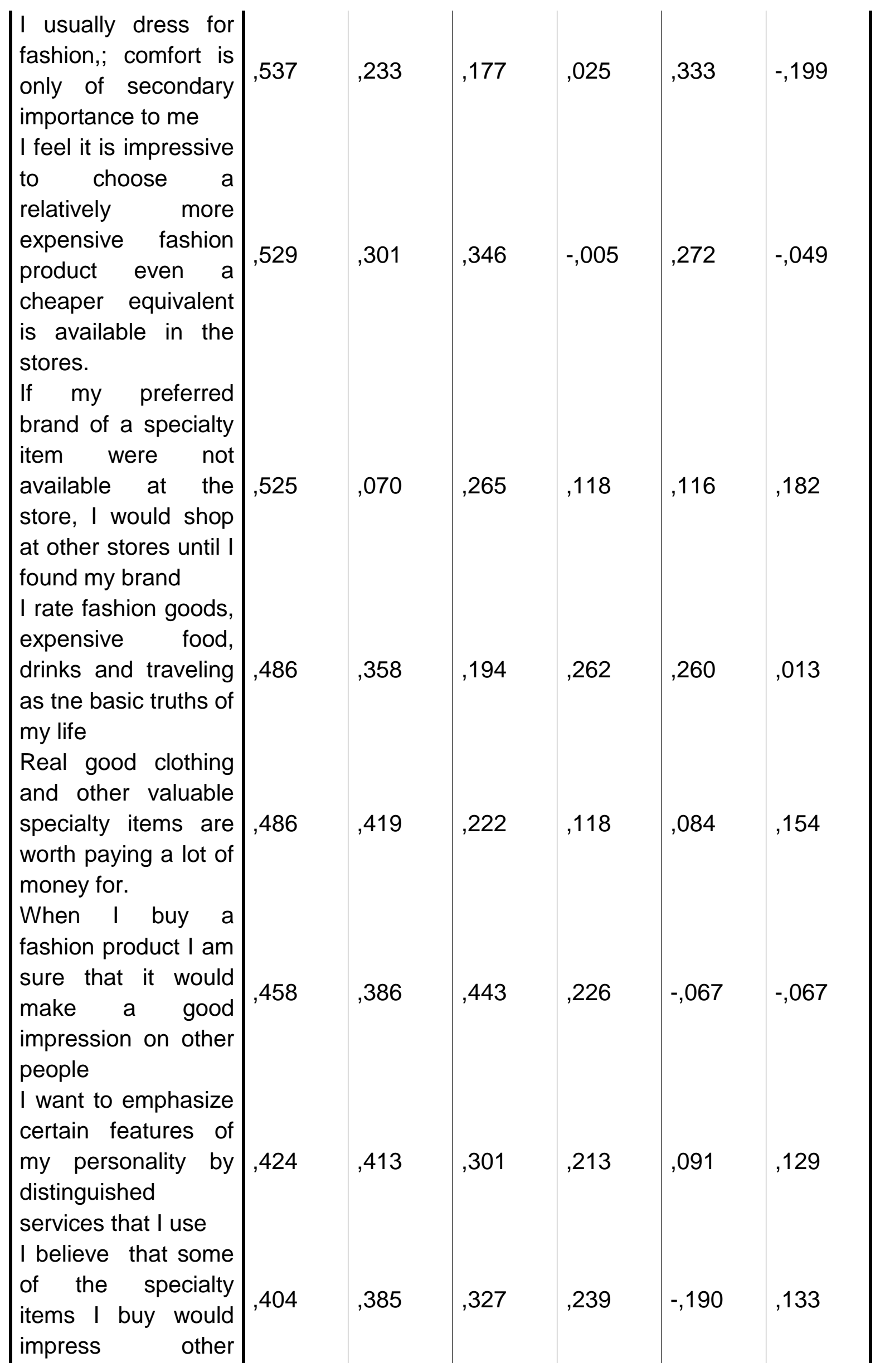




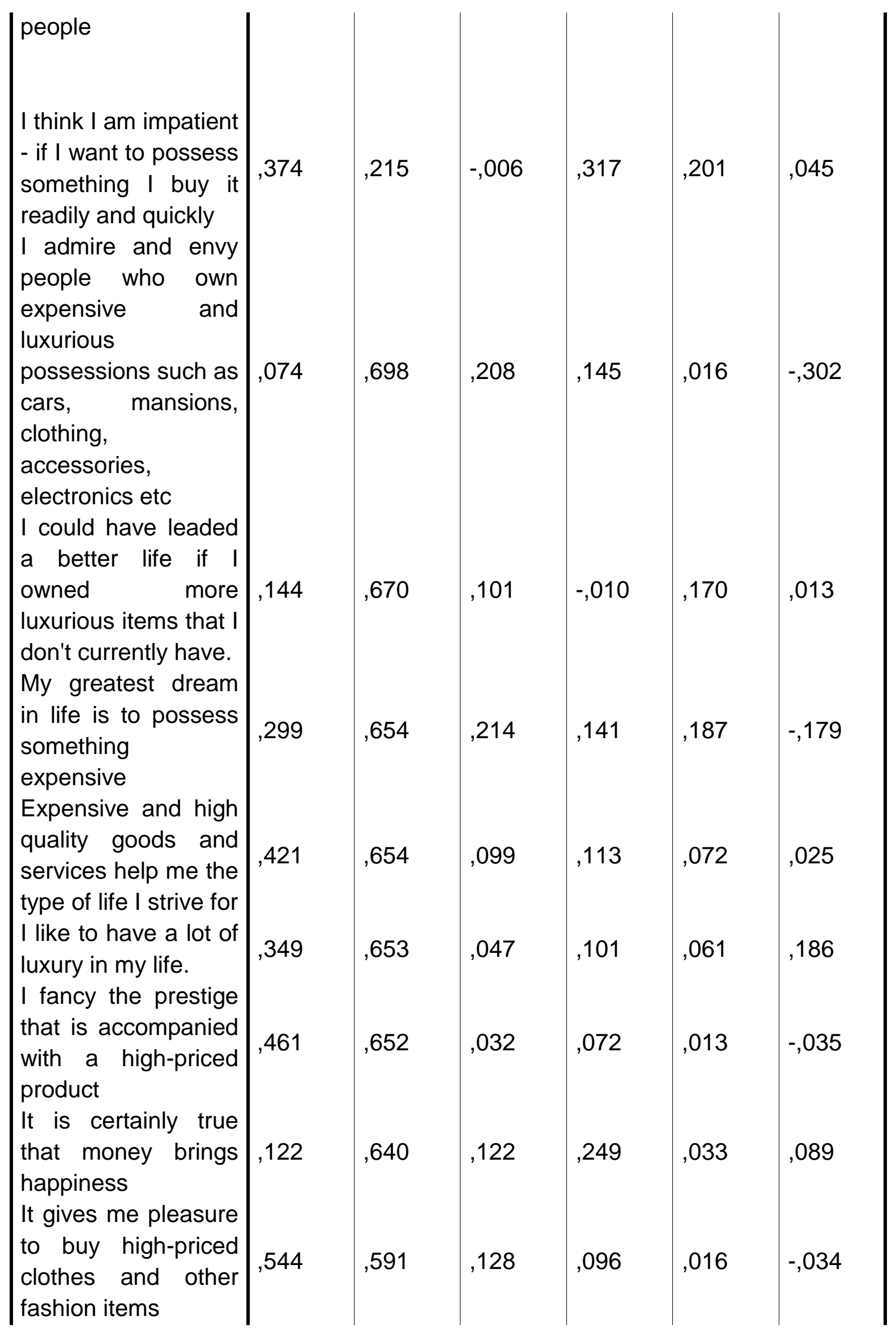




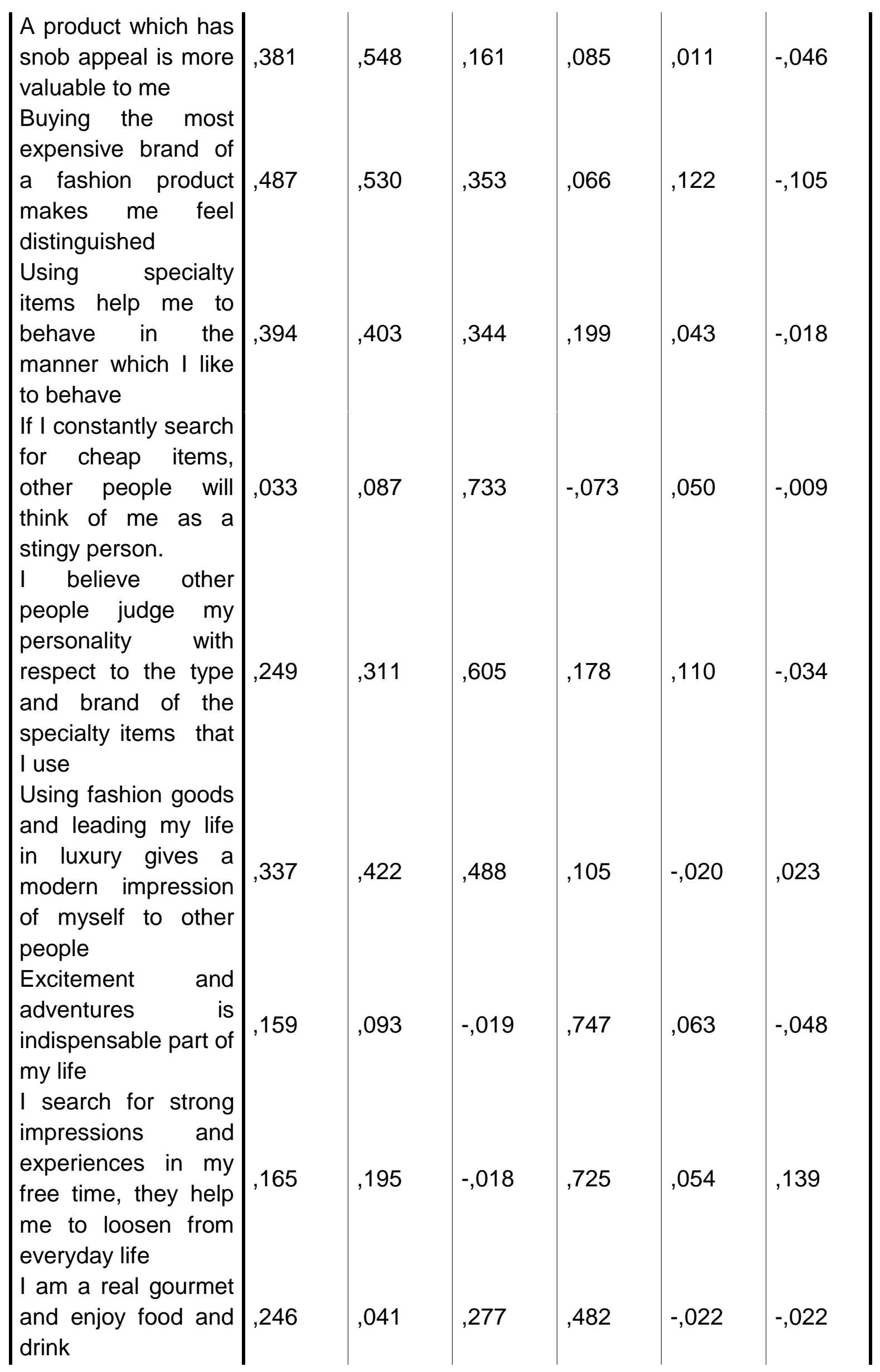




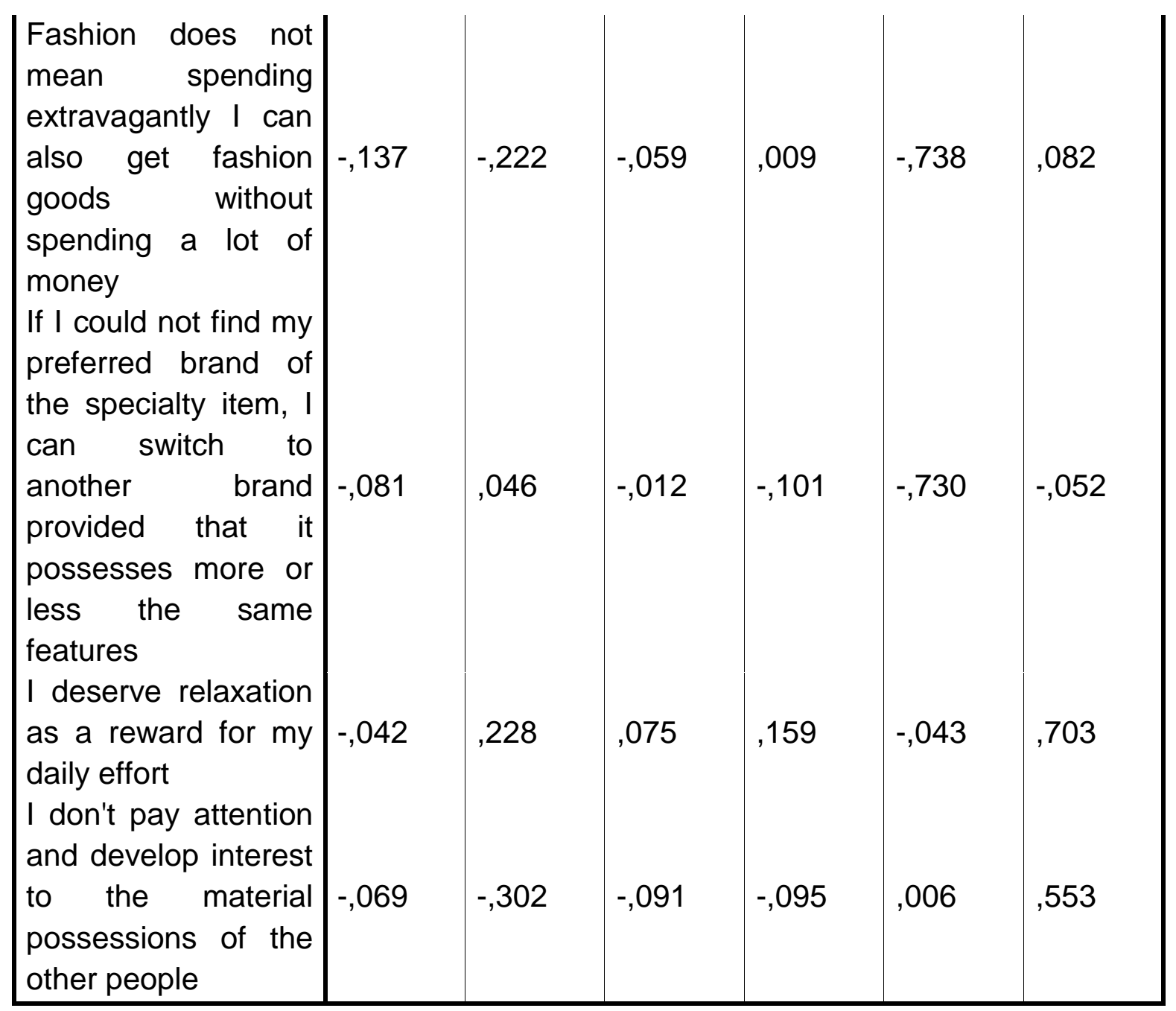

KMO (Kaiser-Meyer-Olkin Measure of Sampling Adequacy = 0.967 Overall Scale Reliability $=0.935$

\section{Findings}

Consumer traits as brand loyalty, innovativeness and opinion leadership is closely related with all levels of fashion involvement. The strongest ties happens to be with innovativeness. In other words innovativeness is the key factor which explains fashion involvement. Compulsive buying behavior elements such as impatience, excitement and impression lead to materialistic buying behavior. From involvement point of view, high involvement in fashion products neglects price sensitivity. That is such consumers are prone to purchase expensive items and do not pay much attention to the price of the product. Among demographic factors, high income level is unanimously the best determinant of hedonic consumption behavior.

Demographic factors also play an important role on fashion involvement. In this context, self employed professionals (doctors, lawyers, architects, certified accountants and other free-lance workers) and managers call themselves as fashion followers and try to create a good impression in the eyes of other people. Young adults (26-40 years) gets pleasure to buy high-priced clothes and other fashion items. Females are less sensitive to price than males as far as fashion goods purchases 
are concerned. Compulsive buying behavior prevails among the youngest generation $(18-25$ years) and the highest income bracket $(+\$ 3600)$ who show impatience and if they want to possess something they buy it readily and quickly. Excitement and adventures are the most indispensable parts of the youngsters' lives. Businessmen are the consumer group who think that they deserved relaxation for their daily efforts. Brand loyalty is least considered among housewives with respect to other occupational groups. Self-employed people are the most brand-loyal consumers. Young adults call them as innovators more than other demographic groups do. Selfemployed people also serve as opinion leaders. University graduates and younger generation like to purchase specialty items to impress other people. Young adults seek for prestige accompanied with a high-priced products. Possessing something expensive and with snob appeal is a dream for self-employed consumers. Senior citizens, housewives and lower income group (\$451-900) consumers don't pay attention and develop interest to the material possessions of the other people. Yearning for luxury in one' $s$ life is a common trait for all consumer groups where young adults, females, businessmen university graduates and highest income group predominate the others.

\section{References}

Alba, J.W., and Hutchiınson, J.W., "Dimensions of Consumer Expertise", Journal of Consumer Research, (March, 1987), No: 13

Dhar, R. and Wertenbroch, K., "Consumer choice between hedonic and utilitarian goods", Journal of Marketing Research, Vol. 37, February, pp. (2000)/ 60-71.

Hirschman, Elizabeth C., and Holbrook, Morris B., "Hedonic Consumption: Emerging Concepts, Methods, and Propositions"., Journal of Marketing (pre-1986); Summer 1982

Izard, C: E. and Buechler, S., "Aspects of Consciousness and Personality in Terms of Differential Emotions Theory"., Robert Plutchic and Henry Kellerman eds., New-York, Academic Press

Johnson, Tricia and Attman, Julianne, "Compulsive Buying in a Product Specific Context: Clothing", Journal of Fashion Marketing and Management, Vol. 13 No. 3, 2009

Kang Jiyun, and Park-Pops, Haesun, "Hedonic and Utilitarian Shopping Motivations of Fashion Leadership"., Journal of Fashion Marketing and Management, Vol. 14 No. 2, 2010 
Lockshin, Lawrence S. And Rhodus, Timothy W., "The Effect of Price and Oak Flavor on Perceived Wine Quality"., International Journal of Wine Marketing5. 2,3 (1993)

Neeley, Concha R., Min, Kyeong Sam, and Kennett-Hensel, Pamela A., "Contingent Consumer Decision Making in the Wine Industry: The Role of Hedonic Orientation"., Journal of Consumer Marketing, 27/4 (2010)

Park, Eun Joo; Kim, Eun Yang, and Forney, Judith Cardona, "A Structural Modelof Fashion-Oriented Impulse Buying Behavior"., Journal of Fashion Marketing and Management, Vol. 10 No. 4, 2006

Palazon Mariola and Delgado-Ballester Elena, "Hedonic or Utilitarian Premiums: Does it Matter?", European Journal of Marketing Vol. 47 No. 8, 2013 pp. 1256-1275

Ryan, Lisa, and Dziurawec, Suzanne, "Materialism and its Relationship to Life Satisfaction”., Social Indicators Research; Aug 2001

Ryu Kisang, Han Heesup, and Jang Shawn, "Relationships Among Hedonic and Utilitarian Values, Satisfaction and Behavioral Intentions in the Fast-Casual Restaurant Industry", International Journal of Contemporary Hospitality Management Vol. 22 No. 3, 2010 pp. 416-432

Sato, Ayana, and Verplanken, Bas, "The Psychology of Impulse Buying: An Integrative Self-Regulating Approach"., Journal of Consumer Poliy, (2011), No: 34

Sobel, M.E., "Asymptotic confidence intervals for indirect effects in structural quation models", in Leinhardt, S. (Ed.), Sociological Methodology, American Sociological sociation, Washington, DC, (1982) pp. 290-312.

Solomon Michael R., Consumer Behavior: Buying, Having, and Being, Pearson Prentice-Hall Inc., (Australia, 2004) 